\title{
LONG-TERM FSO/FPSO CHARTER RATE ESTIMATION
}

\author{
Hesty A Kurniawati ${ }^{1}$, Wasis D Aryawan ${ }^{1}$, Achmad Baidowi \\ 1) Department of Naval Architecture, Faculty Of Marine Technology, Sepuluh November Institut of \\ Technology, Indonesia \\ Email: tita@na.its.ac.id
}

\begin{abstract}
Most of the charter rate data provided in the market is for the short-term and it is based on freight rate for cargo ships. This paper offers a method to estimate long-term charter rate for special ships such as FSO and other supporting vessels. The method is utilizing engineering economy such as IRR and goal seek facility provided in spreadsheet. The IRR is iterated $2 \%$ above the basic saving interest rate to find more attractive charter rate and the sensitivity analysis provides flexibility for the owner in order to anticipate the volatility of economic condition
\end{abstract}

Keywords: FSO/FPSO, Charter Rate, IRR

\section{INTRODUCTION}

The World demand of energy is increasing day by day.The crude oil growth of demand is around $43 \%$ in a span of 20 years $(1990-2010)$, in order to meet this heavy demand world offshore production has risen three times to 53 million barrels per day in a span of 10 years ${ }^{1}$, meanwhile the world natural gas consumption grew by $2.2 \%$ below the historical average $2.7 \%$. But for the southeast natural gas market, there is a huge gap between the supply and demand, the gap is around $9 \mathrm{bcf} / \mathrm{d}^{2}$ as shown in Fig.1

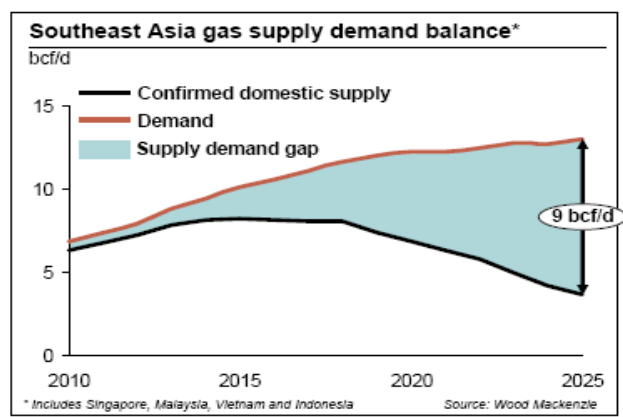

Fig.1 Southeast Asia gas supply and demand

One of production facilitywhich has been widely used in offshore oil or gas production are Floating Production Storage and Offloading (FPSO) or Floating Storage and Offloading (FSO). In fact, the largest population of FPSO is in Asia region, there are 42 FPSO in Asia region and it represents $23.2 \%$ FPSO population all over the world as shown in Table. 1

Table.1 FPSO per region

\begin{tabular}{lr}
\hline Region & Number \\
\hline Asia/Far east & 42 \\
West Africa & 41 \\
South America & 39 \\
Europe & 25 \\
Australia/New Zealand & 13 \\
Mediterranean/Black Sea & 5 \\
US Gulf Mexico & 3 \\
Canada & 2 \\
Indian Ocean & 1 \\
Idle & 10 \\
\hline Total & 181 \\
\hline
\end{tabular}

Most of the FPSOs in the world are leased FPSOs for 15 years or more. The growth of FPSO usage in the world is $81 \%$ marked by the number of FPSO has increased from 90 to 180 from 2004 to 2013 units as shown in Fig.2. This indicates the necessity of charter or lease rate estimation is very important.

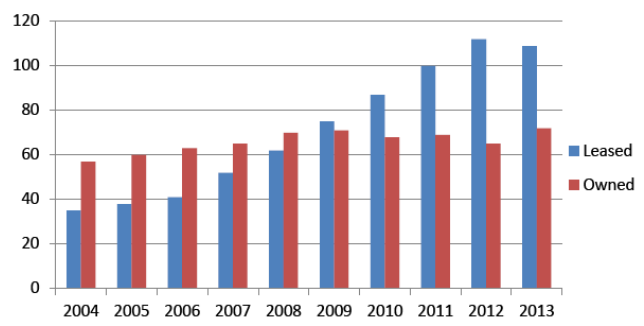

Fig. 2 . Number Of FPSO from 2004 to 2013

Most of the charter rate estimations are defined based on spot rate of voyage charter provided in the future market. Spot market provides historical data of charter rate and it is volatile, Seasonality has an important implication for market participants4. There are 4 main groups of freight market, dry bulk, Tanker, Container and other types of ships1, the special ships 
charter rate such as FSO/FPSO is difficult to find in the market data, most of the market data and economic model of charter rate is for short term.

Based on backgrounds mentioned previously, this paper proposes a method to estimates the charter rate based on engineering economy principles, in this case based on NPV and IRR.

\section{METHOD}

\subsection{Revenue}

Revenue is generated by the charter rate fee paid by the charterer,the operating days will be vary depend to the maintenance schedule.

\subsection{Capital Cost}

The investment cost is representing the total amount of assets or money which must spent by the owner to gain in order to finance the investment.

\subsection{Operating Cost}

Operating costs, which constitute the expenses involved in the day-to-day running of the ship - essentially those costs such as crew, stores and maintenance that will be incurred whatever trade the ship is engaged in ${ }^{8}$, The common components of operating cost are:

- Crew Cost

- Maintenance and Repairs

- Administration and general charges

- Lubrication Oil

- Insurance

- Provisions and stores

- Voyage Cost

The total annual operating cost strongly influenced by the maintenance schedule,the operating cost must be covered for all the economic lifetime of the ship,a ship must follows maintenance and survey schedule, ideally the survey requires the ship to be docked,so the annual cost will be increases due to the docking.

\subsection{Capital Budgeting in Engineering Economy}

Estimation method of long term charter rate for special ships such as FSO,are still relatively rare, this paper proposes a method to estimate the long-term charter rate of an FSO based on engineering economy analysis. Engineering economy is an approach of design to meet maximum effectiveness in the use of scarce resources: man-power,materials (including fuel), machinery and spare money ${ }^{5}$. This method utilizes capital budgeting principles to assess the feasibility of an investment. There are several known criteria of capital budgeting such Net Present Value (NPV), Internal Rate of Return (IRR), Cost and Benefit Ration(C/B ratio). In this study IRR and NPV in this case FSO/FPSO charter rate, the project must fulfill at least two criteria, first, is theNet Present Value(NPV).The net present values $(N P V)$ of income and expenditure are calculated over the assumed life time of the ship $(N)$ years, the final sum should be positive for the investment to be profitable at the assumed discount rate - or where alternatives are being compared it should be the larger sum.

$N P V=\sum_{t=0}^{N} \frac{\bar{C} F_{t}}{(1+r)^{t}}$

Where :

$r$ is the cost of capital

$t$ is time of project

$C F$ is Cash Flow

The second requirement is the Internal Rate of Return (IRR), this method requires that the rate of return is at least equal or higher than the saving interest rate offered by commercial Bank ${ }^{6}$.

$$
N P V=\sum_{t=0}^{-} \frac{C F_{t}}{(1+I R R)^{t}}=0
$$

The financial performances and investment strategy of the project must be able to make the ship owner survive in the shipping market, there are three key variables which ship-owners have to work with ${ }^{7}$, and those variables are:

- The revenue received from chartering/operating the ship;

- The cost of running the ship;

- The method of financing the business The decomposition of those three variables has been conducted based on general structure of the cost and revenue structure. 


\subsection{Net Cash Flow}

The component of cash flow consist of :

- Revenue

- Total Cost

- $\quad$ Earnings before tax

- Tax

- $\quad$ Net cash flow

- $\quad$ Cumulative cash flow

Based on the cumulative cash flow the Break Even Point of the investment can be determined, A break even is achieved when the value of the cumulative cash flow is positive or even to all investment cost.

\section{CHARTER RATE OF FPSO/FSO}

Based on the method proposed in the previous section. A case study based on the charter requirements as given in Table 2. The assumptions is the FSO will be chartered for 20 years in time charter scenario. The time charter assumes that maintenance cost, docking, lubrication, fuel oil, crew cost is the owner responsibility. But the scenario still adjustable based on the agreement between ship-owner and charterer.

Table 2 Assumptions and parameters of the FSO

\begin{tabular}{lll}
\hline $\begin{array}{l}\text { Economic Life time } \\
\text { of the ship }\end{array}$ & 20 & years \\
\hline Capital Cost & $50,000,000$ & US\$ \\
\hline LOA & $261 \mathrm{~m}$ & $\mathrm{~m}$ \\
\hline Breadth & 39 & $\mathrm{~m}$ \\
\hline Depth & 23.1 & $\mathrm{~m}$ \\
\hline Draft & 15.25 & $\mathrm{~m}$ \\
\hline $\begin{array}{l}\text { Salvage value } \\
\text { ship }\end{array}$ & $5,000,000$ & US\$ \\
\hline Contract period & 20 & Years \\
\hline
\end{tabular}

\subsection{Charter Revenue}

It is assumed the operating days is 365 days when there is no docking schedule, and assumed 345 when there is a schedule for the ship needs to be docked,the charter rate will be calculated per day,the first 10 years of the rate assumed flat or in the same amount due the contract is for 10 years, the next 5 years decreases $50 \%$ from the first year,and the last 10 years assumed $30 \%$ from the first year rate,this assumption is based on the decreasing performance of the ship due to the depreciation. The decreasing rate must be adjusted to the condition.

\subsection{Capital Cost}

This paper assumed that the owner uses loan from a bank to finance $75 \%$ of the total capital cost. The rest of the capital (25\%) came from the owner. The maturity of loan assumed is 5 years, The interest rate is $10 \%$, payment per year is once a year.

The total payment per year which consist of principal payment and the interest payment is US\$ 9,892,405.53. The detail of the annual payment for 5 years described in Table 3 .

Table 3 Annual Payment for 5 years

\begin{tabular}{|c|c|c|c|c|c|c|}
\hline & 0 & 1 & 2 & 3 & 4 & 5 \\
\hline SALVAGE VALUE & US\$ & $5,000,000.00$ & $47,631,578.95$ & $45,263,157.89$ & $42,894,736.84$ & $40,526,315.79$ \\
\hline $\begin{array}{l}\text { DEPRECIATION } \\
\end{array}$ & US\$ & $(2,368,421.05)$ & $(2,368,421.05)$ & $(2,368,421.05)$ & $\begin{array}{l}(2,368,421.05) \\
\end{array}$ & $(2,368,421.05)$ \\
\hline BEGINNING BALANCE & US\$ & $37,500,000.00$ & $31,357,594.47$ & $24,600,948.39$ & $17,168,637.70$ & $8,993,095.94$ \\
\hline INTEREST PAYMENT & USS & $(3,750,000.00)$ & $(940,727.83)$ & $(738,028.45)$ & $(515,059.13)$ & $(269,792.88)$ \\
\hline PRINCIPAL REPAYMENT & US\$ & $(1,842,721.66)$ & $(1,842,721.66)$ & $(1,842,721,66)$ & $(1,842,721.66)$ & $(1,842,721.66)$ \\
\hline ENDING BALANCE & US\$ & $31,357,594.47$ & $24,600,948.39$ & $17,168,637.70$ & $8,993,095.94$ & 0.00 \\
\hline TOTAL PAYMENTS & USS & $(9,892,405.53)$ & $(9,892,405.53)$ & $(9,892,405.53)$ & $(9,892,405.53)$ & $(9,892,405.53)$ \\
\hline
\end{tabular}

\subsection{Operating Cost}

This paper considers two type of survey or docking as part of the operating cost. The intermediate survey and special survey. The intermediate survey cost is US\$75,000 and the special survey docking is US\$100,000 while the regular maintenance cost is US\$50,000.

The detail of operating cost is shown in Table 4 .

Table 4. Total Operating cost

\begin{tabular}{lrrr}
\hline & Annual & $\begin{array}{c}\text { Intermediate } \\
\text { survey }\end{array}$ & Special Survey \\
\hline Crew & 201,196 & 201,196 & 201,196 \\
\hline Maintenance \& Repairs & 50,000 & 75,000 & 100,000 \\
\hline Admin and charges & 25,000 & 25,000 & 25,000 \\
\hline Lub Oil & 6,000 & 6,000 & 6,000 \\
\hline Insurance & 600,000 & 600,000 & 600,000 \\
\hline Provisions and stores & 50,000 & 50,000 & 50,000 \\
\hline Total Annual Cost & 932,196 & 957,196 & 982,196 \\
\hline Total Operating Cost & $\mathbf{9 3 2 , 1 9 6}$ & $\mathbf{9 5 7 , 1 9 6}$ & $\mathbf{9 8 2 , 1 9 6}$ \\
\hline
\end{tabular}

There are several basic assumptions used in this calculation which can be shown in Appendix 1

\subsection{Charter Rate and Sensitivity Analysis}

The charter rate is calculated based on IRR. In order to make the investment is feasible, the charter rate must provide higher IRR compared to the bank saving interest rate.

In this paper the value of IRR is simulated between $10 \%-20 \%$. Table 5 shows the scenario of IRR, profit and Charter rae from $10 \%$ up to $20 \%$. The scenario is required to obtain sensitivity of charter rate against targeted IRR. 
Table 5. Variation of Charter rate

\begin{tabular}{ccr}
\hline IRR & PROFIT & $\begin{array}{c}\text { CHARTER RATE } \\
\text { (US\$) }\end{array}$ \\
\hline $10 \%$ & $0 \%$ & 24,380 \\
\hline $12 \%$ & $2 \%$ & 26,021 \\
\hline $14 \%$ & $4 \%$ & 27,617 \\
\hline $16 \%$ & $6 \%$ & 29,181 \\
\hline $18 \%$ & $8 \%$ & 30,713 \\
\hline $20 \%$ & $10 \%$ & 32,214 \\
\hline
\end{tabular}

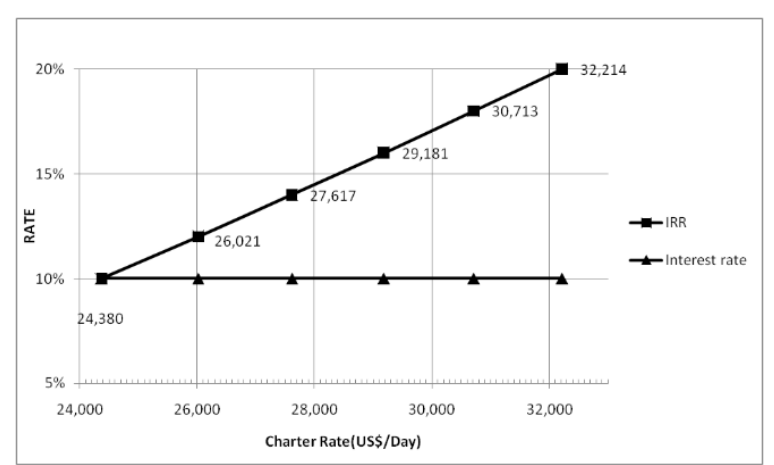

Fig. 3. Variation of charter rate and IRR

It is can be found from Fig. 3. That the minimum charter rate is US $\$ 24,380$ per day, this value is defined based on the bank saving interest rate $10 \%$.

Table 6. NPV values based on variation of IRR

\begin{tabular}{cccc}
\hline IRR & PROFIT & \multicolumn{1}{l}{$\begin{array}{l}\text { NPV } \\
\text { (US\$) }\end{array}$} \\
\hline $10 \%$ & $0 \%$ & $\$$ & - \\
\hline $12 \%$ & $2 \%$ & $\$$ & $2,937,075$ \\
\hline $14 \%$ & $4 \%$ & $\$$ & $5,793,763$ \\
\hline $16 \%$ & $6 \%$ & $\$$ & $8,593,280$ \\
\hline $18 \%$ & $8 \%$ & $\$$ & $11,335,502$ \\
\hline $20 \%$ & $10 \%$ & $\$$ & $14,072,381$ \\
\hline
\end{tabular}

Beside sensitivity analysis IRR and charter rate, it is also required to conduct sensitivity analysis of IRR and NPV as shown in Table 6.

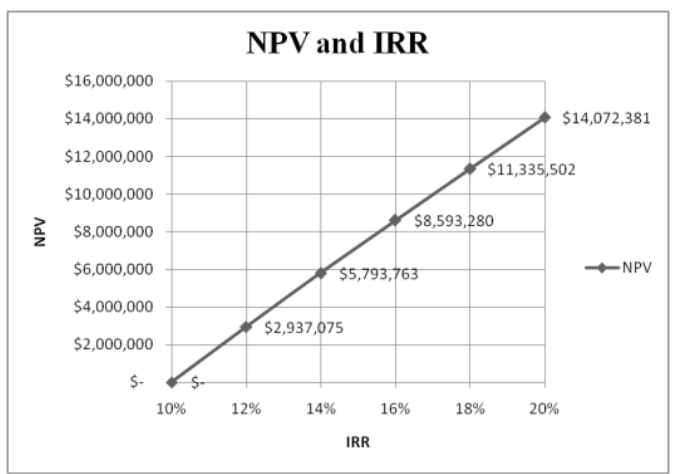

Fig. 4. Iteration of NPV and IRR
Fig. 4 shows that to obtain profit $0 \%$ to $10 \%$ from the bank saving interest, the NPV shall be from US\$2,937,075 to US\$14,072,381. The complete calculation of charter rate at $16 \%$ of IRR presented by Appendix 2

\section{CONCLUSION}

Long-term charter rate of an FSO/FPSO can be defined by using capital budgeting principle where the evaluation criteria are the NPV and IRR. By conducting IRR iteration gradually $2 \%$ above the basic IRR or basic saving interest rate will provides ship owner sensitivity against the volatility of the saving interest rate.

For this case the mean value or the moderate charter rate value is at US\$8,757 at $16 \%$ IRR (6\% higher than saving interest rate).This Method provides flexibility both for owner and charterer to estimate the long term charter rate in the volatile or uncertain condition.

Acknowledgement, we are grateful for the assistance of LPPM ITS for providing required data.

\section{REFERENCES}

[1] Balram S.,Karimi I.A.,2009,Crude oil transshipment using floating, storage, and offloading platforms(FSOPs), $10^{\text {th }}$ International symposium on process systems engineering-PSE2009,pp:2085

[2] BP,2013,BP Statistical review of world energy,june 2013, British Petroleum,pp:4

[3] Tepstra et.al,2013, Offshore dry-docking of FPSOs; a response to industry needs, Offshore Technology Conference Brasil,pp:4

[4] P. Kasra. 2011. Essays on the econometric modelling and forecasting of shipping market variables $\mathrm{PhD}$ Thesis,Newcastle University.

[5] Benford. H., 1981. Fundamentals of ship design economics. department of naval architecture and marine engineering. University Of Michigan.

[6] Newman et.al, 2004, engineering economic analysis: 9th Edition, Oxford University press pp: 124

[7] Buxton. 1972. Engineering Economics and Ship Design. Royal Instituion Of Naval Architect (RINA).

[8] M. Stopford. 2003. Maritime Economics:second edition. Routledge.London.pp:153 
Appendix 1. Basic assumptions of charter rate

\begin{tabular}{|l|l|l|r|}
\hline 1. & CAPITAL COST SUMMARY & \multicolumn{2}{|c|}{} \\
\hline 1.1 & Capital Cost(conversion and ship price) & US $\$$ & $50,000,000$ \\
\hline
\end{tabular}

\begin{tabular}{|l|l|c|c|}
\hline 2. & OPERATING COST SUMMARY & \multicolumn{2}{|c|}{} \\
\hline 2.1 & Crew & US\$ & 201,196 /year \\
\hline 2.2 & Maintenance \& Repairs & US\$ & 50,000 /year \\
\hline 2.3 & Administration \& general charges & US\$ & 25,000 /year \\
\hline 2.4 & Lub oil & US\$ & 6,000 /year \\
\hline 2.5 & Insurance & US\$ & 600,000 /year \\
\hline 2.6 & Provisions and stores & US\$ & 50,000 /year \\
\hline 2.7 & Total Operating Cost & US\$ & 882,196 /year \\
\hline
\end{tabular}

\begin{tabular}{|l|l|c|c|}
\hline 3. & VOYAGE COST SUMMARY & \multicolumn{2}{|l|}{} \\
\hline 3.1 & Bunkers & US\$ & - /year \\
\hline
\end{tabular}

\begin{tabular}{|l|l|r|r|r|}
\hline 4. & FINANCIAL SUMMARY & \multicolumn{3}{|c|}{5} \\
\hline 4.1 & Maturity of loan & & 1 & \\
\hline 4.2 & Payment per year & & year \\
\hline 4.3 & Equity $\$$ & US\$ & $37,500,000$ & $75 \%$ \\
\hline 4.4 & Debt & $\%$ & $10.0 \%$ & \\
\hline 4.5 & Interest rate/year & US\$ & $9,892,406$ & \\
\hline 4.6 & Loan Repayment / Year (Flat) & US\$ & $8,670,383$ & \\
\hline 4.7 & NPV & Year & 25 & \\
\hline 4.8 & Economic Lifetime of ship & US $\$$ & $5,000,000$ & \\
\hline 4.9 & Salvage Value & & \\
\hline
\end{tabular}

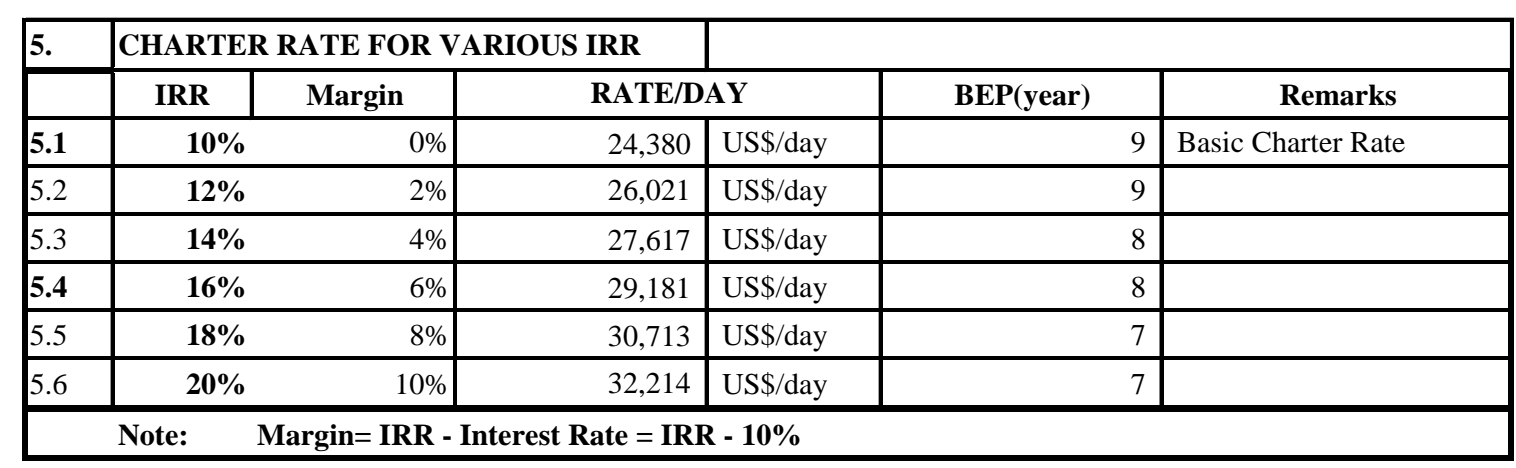


Appendix 2. Charter Rate Spreadsheet
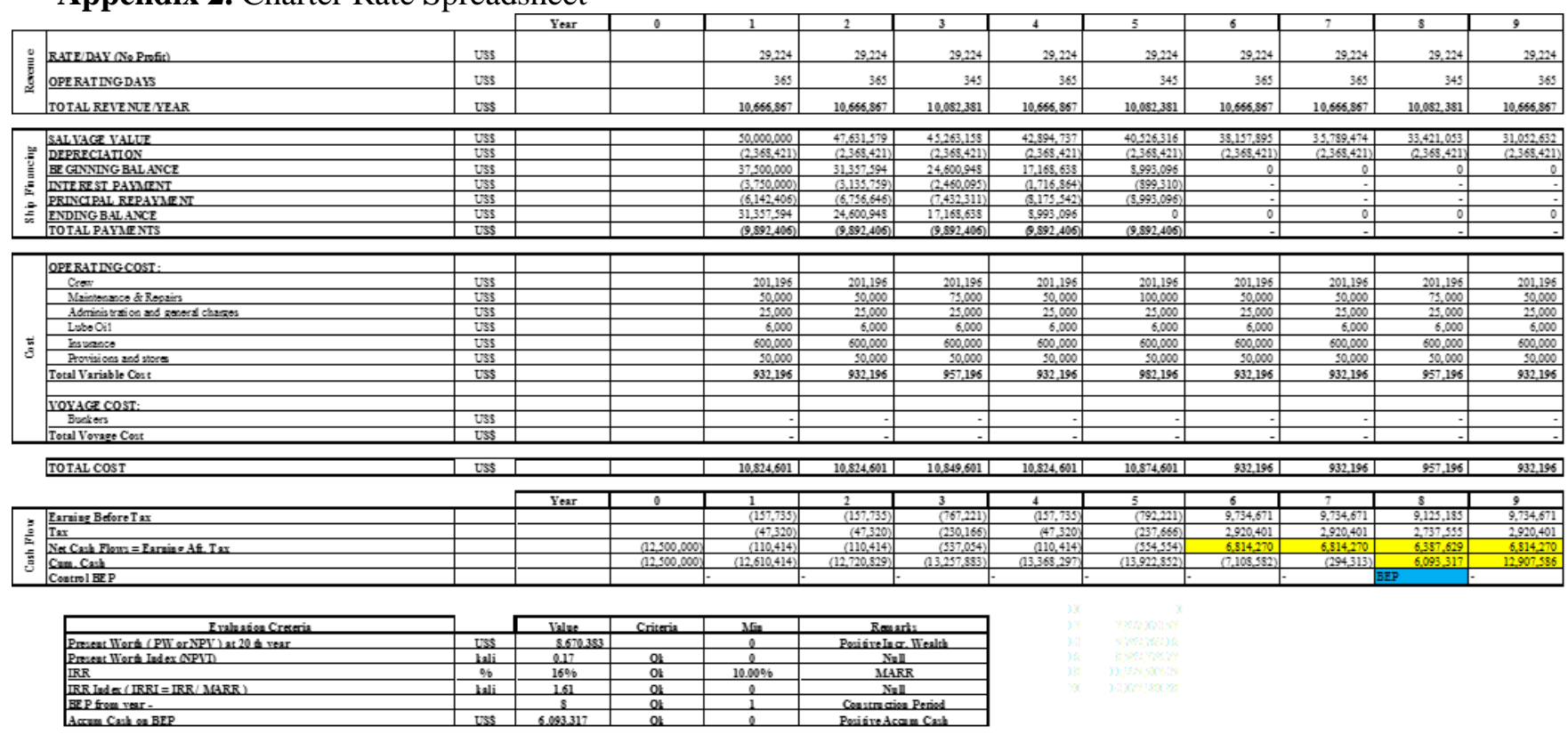

\begin{tabular}{|c|c|c|c|c|c|c|c|c|c|c|}
\hline 10 & 11 & 12 & 13 & 14 & 15 & 16 & 17 & 18 & 19 & 20 \\
\hline 29,224 & 14,612 & 14,612 & 14,612 & 14,612 & 14,612 & 8,767 & 8,767 & 8,767 & 8,767 & 8,767 \\
\hline 345 & 365 & 365 & 345 & 365 & 345 & 365 & 365 & 345 & 365 & 345 \\
\hline $10,082,381$ & $5,333,433$ & $5,333,433$ & $5,041,190$ & $5,333,433$ & $5,041,190$ & $3,200,060$ & $3,200,060$ & $3,024,714$ & $3,200,060$ & $3,024,714$ \\
\hline $28,684,211$ & $26,315,789$ & $23,947,368$ & $21,578,947$ & $19,210,526$ & $16,842,105$ & $14,473,684$ & $12,105,263$ & $9,736,842$ & $7,368,421$ & $5,000,000$ \\
\hline$(2,368,421)$ & $(2,368,421)$ & $(2,368,421)$ & $(2,368,421)$ & $(2,368,421)$ & $(2,368,421)$ & $(2,368,421)$ & $(2,368,421)$ & $(2,368,421)$ & $(2368,421)$ & $(2,368,421)$ \\
\hline 0 & 0 & 0 & 0 & 0 & 0 & 0 & 0 & 0 & 0 & 0 \\
\hline- & - & - & - & - & - & - & - & - & - & - \\
\hline & & - & - & - & - & - & - & - & - & - \\
\hline 0 & 0 & 0 & 0 & 0 & 0 & 0 & 0 & 0 & 0 & 0 \\
\hline- & - & -1 & - & - & - & - & - & - & - & $=$ \\
\hline & & & & & & & & & & \\
\hline 201,196 & 201,196 & 201,196 & 201,196 & 201,196 & 201,196 & 201,196 & 201,196 & 201,196 & 201,196 & 201,196 \\
\hline 100,000 & 50,000 & 50,000 & 75,000 & 50,000 & 100,000 & 50,000 & 50,000 & 75,000 & 50,000 & 100,000 \\
\hline 25,000 & 25,000 & 25,000 & 25,000 & 25,000 & 25,000 & 25,000 & 25,000 & 25,000 & 25,000 & 25,000 \\
\hline 6,000 & 6,000 & 6,000 & 6,000 & 6,000 & 6,000 & 6,000 & 6,000 & 6,000 & 6,000 & 6,000 \\
\hline 600,000 & 600,000 & 600,000 & 600,000 & 600,000 & 600,000 & 600,000 & 600,000 & 600,000 & 600,000 & 600,000 \\
\hline 50,000 & 50,000 & 50,000 & 50,000 & 50,000 & 50,000 & 50,000 & 50,000 & 50,000 & 50,000 & 50,000 \\
\hline 982,196 & 932,196 & 932,196 & 957,196 & 932,196 & 982,196 & 932,196 & 932,196 & 957,196 & 932,196 & 982,196 \\
\hline & & & & & & & & & & \\
\hline & & & & & & & & & & \\
\hline & - & - & - & - & - & - & - & - & - & \\
\hline & - & - & - & - & - & - & - & - & - & - \\
\hline $1,964,392$ & & & & & & & & & & \\
\hline 982,196 & 932,196 & 932,196 & 957,196 & 932,196 & 982,196 & 932,196 & 932,196 & 957,196 & 932,196 & 982,196 \\
\hline 10 & II & 12 & 13 & 14 & 15 & 16 & 17 & 18 & 19 & 20 \\
\hline $9,100,185$ & $4,401,237$ & $4,401,237$ & $4,083,994$ & $4,401,237$ & $4,058,994$ & $2,267,864$ & $2,267,864$ & $2,067,518$ & $2,267,864$ & $2,042,518$ \\
\hline $2,730,055$ & $1,320,371$ & $1,320,371$ & $1,225,198$ & $1,320,371$ & $1,217,698$ & 680,359 & 680,359 & 620,255 & 680,359 & 612,755 \\
\hline 6.370 .129 & 3.080 .866 & 3.080 .866 & 2.858 .796 & 3.080 .866 & 2.841 .296 & 1.587 .505 & 1.587 .505 & 1.447 .263 & 1.587 .505 & 6.429 .763 \\
\hline $19,277,715$ & $22,358,582$ & $25,439,448$ & $28,298,244$ & $31,379,110$ & $34,220,406$ & $35,807,911$ & $37,395,416$ & $38,842,679$ & $40,430,184$ & $46,859,946$ \\
\hline 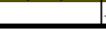 & & 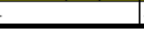 & & & 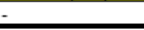 & & 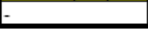 & & 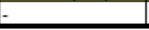 & 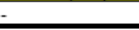 \\
\hline
\end{tabular}

